details, please refer to the two-part report "National Regulatory Frameworks for Transnational Higher Education: Models and Trends" at www.obhe.ac.uk.

\title{
Innovations in the Allocation of Public Funds
}

\begin{abstract}
Jamil Salmi and Arthur Hauptman
Jamil Salmi is coordinator of the World Bank's Tertiary Education Thematic Group. Arthur Hauptman is an independent public policy consultant specializing in higher education finance issues. Address: The World Bank, 1818 H St. NW, Washington, DC 20433, USA. E-mail: Salmi: jsalmi@worldbank.org; Hauptman: hauptman_a@yahoo.com. This article is drawn from a forthcoming World Bank paper on allocation mechanisms.
\end{abstract}

$\mathrm{T}^{\mathrm{n}}$ recent decades, a growing number of countries have 1 sought innovative solutions to the substantial challenges they face in financing tertiary education. One of the principal challenges, the demand for education beyond the secondary level, is growing in most countries around the world far faster than the ability or willingness of governments to provide adequate public resources.

The reasons for this rapid increase in demand are numerous. First, in virtually all countries, the economic value of attaining a tertiary education, as measured by rates of return or other factors, is growing faster than the economic returns accruing to those who receive a secondary education or less. Second, in many cultures strong social pressures are exerted on students for moving beyond the secondary level of education based on nonmonetary factors such as greater social standing and prestige in the community-sometimes even better marriage prospects for girls. Third, many countries are attempting to increase the relevance of tertiary education curricula as governments and tertiary education institutions deemphasize certain fields with low levels of labor force demand, such as public administration and education, in favor of fields more closely linked to emerging labor force needs, such as information technology, engineering, and science.

The demands placed on public resources are typically intense as governments around the world face challenges across the board in providing better health care, housing, transportation, agriculture, as well as the full range of education. In this context, tertiary education is often far from the highest priority for public funding in both industrial and developing countries.

Countries and institutions around the world have responded to this mismatch between available public resources and the growing demand for tertiary education in several generic ways. The most frequent response has been to mobilize more resources, principally by introducing or raising tuition fees as a means of increasing cost sharing. Another related response has been to seek increased private resources through the commercialization of research and other private uses of institutional facilities and staff. A third, perhaps less commonly found response, has been an increased reliance on bonds and other forms of creative financing that allow for greater public or private partnerships to provide services related to tertiary education activities.

A related trend has been the development of a variety of innovative allocation mechanisms that allow both public and private funds to go farther in meeting the challenges that tertiary education systems face around the world. Our recent study found these innovative mechanisms cover a broad range of approaches:

1. Funding methodologies for recurrent expenses and capital investment have evolved in a number of countries from the more traditional negotiations of budgets between governments and institutions to increasingly sophisticated funding formulas that aim to insulate allocation decisions from excessive political pressures and encourage desired institutional behavior.

2. As has recently happened in Colorado, some "demandside" voucher systems have been created in which institutional operating subsidies will be distributed through a voucher given to all undergraduates. In some cases, the allocation of fixed funds to institutions is based on the characteristics of enrolled students, an approach that might be referred to as "supply-side" vouchers.

\section{The growing diversity of funding sources has been an important response by governments and institutions to the mismatch between demand and resources.}

3. Performance-based funding mechanisms have been adopted in a number of countries. A portion of funding may be set aside to be distributed to institutions on the basis of a series of performance measures. Performance contracts are negotiated between governments and institutions. Competitive funding is introduced that encourages innovation, greater academic quality, and strengthening institutional management capacity. Another approach includes financing mechanisms that directly pay for results, either as part of the basic funding formula or as a separate set of payments of institutions.

4. In some countries financial aid has been substantially expanded for students with high levels of financial need or academic merit to allow for financing strategies that use higher fees to increase overall institutional resource levels, including student aid in the form of vouchers to stimulate competition among institutions-as an alternative to publicly funded but institutionally administered student aid programs.

5. In a number of countries tax benefits have been created to help students and their families offset the expense of tuition fees, as well as family allowances primarily designed to cover 
the living costs associated with attendance in tertiary education.

6. In many countries around the world student loans have been expanded-including the development of various income-contingent repayment schedules in a half dozen countries over the past two decades in which repayment levels are tied to the amount borrowed and the income of borrowers once they complete their education. Another approach includes a series of creative financing arrangements by which the initial funding of mortgage-type student loans is leveraged to provide higher capital levels through modern financing techniques.

These innovative approaches for allocating public funds hold the promise of helping countries improve the access, equity, quality, relevance, and efficiency of their tertiary education systems. But policymakers and institutional officials must be careful to recognize the obstacles of successful implementation of these innovative approaches-including administrative capacity, transparency, and political feasibility.

\section{LESSONS FROM INTERNATIONAL EXPERIENCE}

Resource mobilization and allocation mechanisms. The growing diversity of funding sources has been an important response by governments and institutions to the mismatch between demand and resources. Similarly, countries should rely on a mix of allocation mechanisms to achieve the objectives they seek for their tertiary education systems.

Mix of allocation instruments. While linking budget allocations to some measure of performance should be a guiding principle, the selection of allocation instrument should depend to a great degree on the policy objectives being sought. Some allocation mechanisms are much better at achieving certain objectives than others. In addition, what works well in one country will not necessarily work well in another. Many of the more innovative allocation approaches require strong government structures and adequate public-resource bases. Many developing and transition countries lack these basic essentials and thus must look to other approaches that do not have these requirements for success.

Policy objectives. Policy discussions in many countries often tend to devolve into general discussions of the need for more access or better quality or greater efficiency. Without precise and accurate definition of the objectives being sought, these policy discussions can easily slide into advocacy exercises in which more of everything is better, with little or no prioritization of goals or objectives.

Links with systems of quality assurance. Governments should be careful not to establish too rigid a relationship between the results of evaluation and accreditation and the amount of funding going to tertiary education institutions. A more effective approach may be to make participation in evaluation and accreditation exercises a criterion for access to additional public funding, rather than a determinant of the amount of that funding.
Political feasibility. Many financing reforms, including establishing or increasing tuition fees, replacing scholarships with student loans, or authorizing private tertiary education institutions to operate are controversial measures. Political difficulty should not be used, however, to delay implementing necessary and important reforms. Expert studies, stakeholder consultations, public debates and press campaigns should be used to minimize the risks of opposition and resistance.

These rules for the road should help stakeholders in developing, transitional, and industrialized countries make the right choices for achieving successful allocation strategies for tertiary education.

\section{The Trouble with Fees}

\section{Michael Shattock}

Michael Shattock is a visiting professor at the Institute of Education, University of London and is a former registrar at the University of Warwick. E-mail:shattock@he.u-net.com.

$\mathrm{O}^{\mathrm{n}}$ n May $5^{\text {th }}$ the new Labour government was returned to office with a parliamentary majority reduced from I6I to 66. While the dominant themes in the election were clearly the Iraq invasion and immigration, the decision to raise tuition fees for higher education students in England was the third most important issue on the doorstep. It was vociferously opposed, with conviction, by the Liberal Democrats, who could and did mobilize the student vote. The issue was also opposed, although one might have thought against their natural instincts, by the Tories. The issue was so controversial that it was only won by the government, even with its previous majority, by 5 votes in the House of Commons in 2004, and very obviously it would not have succeeded if it had been delayed until after the election.

It is difficult to see why the decision was so controversial. Fees of $f_{1}, 200$ are already in force for $2005-2006$ for every undergraduate higher education student in England; and the new decision, while raising the fee level in 2006 to up to $£ 3,000$ (depending on the charge levied by the university), does not demand an up-front payment on entry because the fee is to be paid after graduation on an income-contingent basis, with the government paying the fee at entry. Under means-test arrangements students from disadvantaged backgrounds can receive up to $£ 2,700$ per annum in maintenance grant. Students will thus be better off during their period of study under the new arrangements and will only be required to pay after graduation providing they are earning over $£_{15}$, 000, as against the current average graduating salary of about $£$ I9,000. A strong, secondary argument in favor of the new scheme is that it requires the middle classes, which benefit disproportionately from the higher education system both in terms of entry (over 70 percent of the higher education student population is from the professional and managerial classes) 